\title{
Qualitative Methodology in Education: A Multi-Case Study Focused on the Formative Mediation Area in Portugal and in France
}

\author{
Márcia Aguiar \\ Institute of Education, University of Minho - Portugal \\ marciab_aguiar@hotmail.com \\ Ana Maria Silva \\ Institute of Education, University of Minho - Portugal \\ anasilva@ie.uminho.pt
}

\section{Doi:10.5901/jesr.2013.v3n7p210}

\section{Abstract}

Formative Mediation has arisen as a new and complex area in the field of Education and is questioning the traditional conceptions of curriculum, pedagogical relationship, conflict, citizenship and autonomy. The study we have developed is related to the emerging perspectives that are associated with the field of Education and Training of Adults, where we sought to understand what are the pedagogical dynamics, the professional profiles and the practices correlated with Formative Mediation in Courses of Adult Education and Training (AET Courses) and in the process of Recognition, Validation and Certification of Competences (RVCC) developed in Portugal and in the Validation des Acquis de l'Expérience (VAE) undertaken in France.To accomplish this investigation, we used a predominantly qualitative and emerging design, where inductive analysis prevailed throughout the investigative process. In this sense, we carried out a multi-case study (three cases in Portugal and three cases in France) with nine participants in the investigation: two ETA Mediators, a Diagnosis and Referral Specialist (DRS), three Recognition and Validation of Competences Professionals (RVCPs) and three Professionals working in the VAE process. Autobiographical narratives, participant observations and semi-directive interviews were the techniques used and the data obtained was processed using the emerging and inductive categorisation. In this text, we intend to present the steps and processes used in the data analysis, characterise them and discuss some of the results achieved, while seeking to reflect on the advantages and potentialities of the use of qualitative research methods in the Educational field.

\section{Introduction}

Mediation is a concept that has expanded in recent decades and has increasingly gained some autonomy in terms of its discourses and practices, although there are still some difficulties in its definition, due to the different areas and professionals working in this field.

The professionalization and the institutionalisation of Mediation have received particular attention in recent years, both in terms of theoretical debates and in the research field, which has already revealed positive evidence, in particular, with the approval of professional regulations and certification courses, especially in the area of Family Mediation and Postgraduate Courses - both in the legal and extra-judicial areas, such as in the social and educational domains. Nevertheless, there are still quite a few gaps, particularly in terms of labour legislation and professional/social recognition, so we should invest in its sustained professionalization, i.e. we should conceive Mediation as an independent profession (Freire, 2010; Neves, 2010), which is not "subdued" to the prescribed tasks and even the real ones of other professionals (Bonafé-Schmitt, 2010).

Our research, entitled "Figures of Mediation in Adult Education: A multi-case study, from the experience in Portugal and France", relates to the specific area of Educational Mediation and more specifically that of Formative Mediation in the field of Adult Training. Even so, in this area there is a wide variety of practices and levels of intervention, so it becomes difficult to define the profile of the mediator and his/her type of intervention, training and identity (Silva and Moreira, 2009; Silva, Caetano, Freire, Moreira and Freire, 2010).

In this context, the purpose of our study was to know, understand and analyse the profiles, practices and 
meanings attributed by the professionals participating in the investigation ${ }^{1}$ under the Mediation arising from their fields of action and the processes of Education and Training of Adults (ETA) in Portugal and France.

To meet this purpose, we outlined a set of goals, which are exploratory (descriptive) (Coutinho, 2011, p. 46-47), because we have a problem, where there are not many studies, which implies the need to identify and/or describe characteristics not yet known, to verify the regularity of social phenomena and to select problems or areas that might be the target of interest for the scientific field.

\section{General Objectives}

- To contribute to study and research in the field of Mediation and specifically that of the Formative Mediation in contexts related to the Education and Training of Adults;

- To analyse the real and prescribed practices of the professionals related to the field of Mediation (Formative Mediation) in contexts related to the Education and Training of Adults; and

- To reflect on the profile of the Mediation actors in contexts related to the Education and Training of Adults.

\section{Specific Objectives}

- To know the practices of the ETA Mediators, the Diagnosis and Referral Specialists, the Recognition and Validation of Competences Professionals and the professionals working in VAE;

- To compare the roles and the professional profiles of the ETA Mediators, the Diagnosis and Referral Specialists, the Recognition and Validation of Competences Professionals and the professionals working in VAE;

- To frame the practices of the ETA Mediators, the Diagnosis and Referral Specialists, the Recognition and Validation of Competences Professionals and the professionals working in VAE in the field of Formative Mediation;

- To identify the difficulties of the ETA Mediators, the Diagnosis and Referral Specialists, the Recognition and Validation of Competences Professionals and the professionals working in VAE in the field of the Mediation processes, as framed in the exercise of their official duties;

- To understand the meanings attributed by those professionals to their work in the field of Formative Mediation; and

- To analyse the curricular dynamics of the processes of the Education and Training of Adults within the existing curriculum theories.

In this article, we will present the methodological options that allowed us to meet these goals i.e. what methods and techniques for collecting, analysing and processing of data were underpinning all the work undertaken in relation to the Multi-case Study that was at the centre of all the investigative process.

\section{Design and Paradigms of the Investigation}

The design of our research was developed in an emergent dynamic (Glaser and Strauss, 1967; Patton, 1990; Strauss and Corbin, 2008; Charmaz, 2009) and it was open and flexible, i.e. it was a process built during the study, marked by advances and retreats, settings, adjustments and restructuring, using a logic of progressive discovery and according to an inductive rationality (see Glaser and Strauss, 1967; Demazière and Dubar, 1997; Maroy, 2005, Strauss and Corbin, 2008; Charmaz, 2009).

This was a descriptive and exploratory research (De Ketele and Roegiers, 1999). Descriptive, since it aimed to describe, analyse and interpret/reflect on practices, behaviours, professional profiles and perspectives of actions of the professionals working in Formative Mediation, which might lead to further investigations. Exploratory, given its heuristic nature involving observation, discovery, interpretation and reflection, which allowed us to infer conclusions that could be taken as hypotheses to be verified (or not) through new, deductive, studies and with a high degree of generalisation, which were not aspects taken into consideration in this investigation.

With this study, while bearing in mind the pursuit of theoretical saturation, it was not possible to achieve this given

${ }^{1}$ Mediators of Courses of Education and Training of Adults (ETA Mediators), Diagnosis and Referral Specialists (DRS), Recognition and Validation of Competences Professionals (RVCPS), in Portugal and professionals that work in the Validation des Acquis de l'Expérience (VAE) in France. 
the complexity of the processes involved and their different interlocutors, as well as for reasons of limited time and financial resources. However, it was possible to work the comparison of cases, the pattern discovery and the construction of theoretical contributions to the field by means of an understanding of relational, social and professional dynamics with an educational and sociological focus.

Our research has its foundations in the qualitative, constructivist, interpretive and comprehensive paradigm and in the assumptions of phenomenology, symbolic interactionism and ethno-methodology (Kirk and Miller, 1986; Bogdan and Biklen, 1994; Miles and Huberman, 1994; Lessard-Hébert et al., 2005; Coutinho, 2011). In this sense, our research focused on the interpretation of the meanings attributed by the social actors to the phenomena by seeking to describe, explore and explain processes and meanings (Bogdan and Biklen, 1994; Denzin and Lincoln, 1994; Guba and Lincoln, 1994; Haguette, 1995). Table 1 summarises the qualitative research characteristics that we favoured.

Table 1. Characteristics of the Qualitative Investigation

\begin{tabular}{|l|l|}
\hline Item/Dimension & Characteristics \\
\hline Naturalistic & $\begin{array}{l}\text { Puts the emphasis on the natural environments in which the action of the social actors } \\
\text { takes place. }\end{array}$ \\
\hline Descriptive & $\begin{array}{l}\text { The description and the interpretation of contexts and situations that are the basis of the } \\
\text { qualitative research by seeking to "create" a theory. }\end{array}$ \\
\hline Procedural & Focuses on social processes and on the interactions and meanings attributed to them. \\
\hline Inductive & $\begin{array}{l}\text { Goes from the particular to the general in order to make inferences to generate hypotheses } \\
\text { or theories. }\end{array}$ \\
\hline Critique/Constructivist & $\begin{array}{l}\text { Relies on a comparison between the perspectives of the researcher and the subjects to find } \\
\text { the most consensual vision by critical confrontation. }\end{array}$ \\
\hline Holistic & $\begin{array}{l}\text { Seeks to analyse the subjects and the phenomena, as a whole, in order to understand the } \\
\text { various meanings and to build multiple realities. }\end{array}$ \\
\hline Role of the Researcher & $\begin{array}{l}\text { There is a closeness between the researcher and the social actors, assuming a sharing of } \\
\text { the experiences and opinions. The investigator is considered an instrument of the } \\
\text { investigation itself, as the construction of reality is associated with its references and } \\
\text { conceptual frameworks, which depends on his/her posture and on the way he/she conducts } \\
\text { the investigative process. }\end{array}$ \\
\hline Valorisation of Subjectivity & $\begin{array}{l}\text { This is concerned with the meanings that from the experiences that social actors attach to } \\
\text { reality. Social behaviour has an inherent subjective part. }\end{array}$ \\
\hline Design of the Investigation & $\begin{array}{l}\text { The design of the research is ongoing, procedural and emergent (Erlandson, Harris, } \\
\text { Skipper and Allen, 1993). }\end{array}$ \\
\hline $\begin{array}{l}\text { Collection and Analysis of } \\
\text { Data }\end{array}$ & $\begin{array}{l}\text { Relies on unstructured techniques of collection and analysis of data in order to collect as } \\
\text { much information as possible. It is an interactive process of shuttling between collection } \\
\text { and reflection and the analysis of data is itself descriptive and interpretive. }\end{array}$ \\
\hline
\end{tabular}

Source: Adapted from Bogdan and Biklen (1994)

Our choice for the investigation of a qualitative nature - beyond academic reasons and personal preferences - was also related to criteria of socio-professional relevance (Lessard-Hébert et al., 2005, p. 86-90), as we sought to understand the practices, to reflect on professional profiles and to comprehend the work of Mediation in ETA contexts, so that our considerations and interpretations could have practical utility in educational and socio-professional terms.

In summary, the interpretative, phenomenological, hermeneutic, constructivist and ethno-methodological assumptions were our basis for action in terms of collecting and analysing data, as well as on the construction of the design of the entire research project.

\section{Method and techniques of data collection}

According to Lessard-Hébert et al. (2005, p. 167), "qualitative methodologies emphasize two modes of investigation: the case study and comparison, or multicase study" - the latter being the one we used to develop this work i.e. a Multi-case Study comparing the Portuguese and French realities concerning the Mediation actors in the Education and Training of Adults (ETA Courses, process of Recognition, Validation and Certification of Competences in Portugal and VAE process of France). 
There are several authors, who seek to define the case study method by explaining it as a method to understand practices and to study a phenomenon in depth in the natural context in which it occurs and from a holistic perspective (Lüdke and André, 1986; Lessard-Hébert et al., 2005; Sousa, 2009; Stake, 2009; Yin, 2010; Coutinho, 2011).

Despite being a Multi-case Study, each case refers to a specific process, so we worked with several simple cases, which we sought to compare in terms of profiles and professional practices. In Multi-case Studies each case is seen as unique, singular and must be analysed in detail, so that later it can be cross referenced with other cases (Patton, 1990; Stake, 1994; Tuckman, 2000).

Our choice for the Multi-case Study was related largely with the purpose to describe and to interpret, broadly, richly and as deeply as possible, the phenomena that were the object of study.

The Multi-case Study, which is focused on creating grounded theories (Glaser and Strauss, 1967; Bogdan and Biklen, 1994; Strauss and Corbin, 2008; Charmaz, 2009), aims to "discover convergences between multiple cases" (Lessard-Hébert et al. 2005, p. 170). In this regard it is pertinent to define, although in very general terms, what data to collect, what and how to observe the data and about what and how to ask. Thus, despite not having a rigid research design, we developed some semi-structured instruments that allowed us to keep focussed on the important phenomena for the object of study.

We selected representative or typical cases, where "the goal is to capture the circumstances and conditions of an everyday situation or a commonplace" (Yin, 2010, p. 72) According to the definition of Stake $(1994,2009)$, our Multi-case Study is instrumental, because it is not the cases in which we are interested but the phenomena that are inherent to them and that constitute our object of study about which we wanted to get more knowledge. Thus, the cases were not selected by the locality itself but because they had characteristics that were going to meet our problem and what we wanted to analyse, understand and interpret in order to refine the theory.

At the same time, we considered that it is a collective case study (Stake, 1994, 2009), as the cases have been chosen, because we believed that their study would allow a better understanding of the phenomena in question, as well as to enable a more robust and grounded theory by comparison.

Because of the limits underlying the period of the research, we chose "easy access cases" (Stake, 2009, p. 20) but we believed they would prove to be "opportunities to learn" (Stake, 1994, p. 243).

We sought the maximum variation (Merriam, 1998) using a New Opportunities Centre, an Association for Local Development and a Vocational School in Portugal and an University, an Academic Centre for the Validation of Acquired Learning and a Resource Centre for the Validation of Acquired Learning in France. The Academic Centre and Resource Centre were selected during the collection of data and the others before the beginning of the data collection.

By choosing the Multi-case Study, we identified as its main advantage the possibility of using various research techniques in order to study and to understand in phenomenological terms the interactions that developed in the specific contexts of the object of study and the practices of the professionals participating in the investigation.

In a Multi-case Study, "an essential tactic is to use multiple sources of evidence, so that the data converge in a triangular mode" (Yin, 2010, p. 22), so there were several techniques used in gathering information.

Table 2 shows, albeit synthetically, how the techniques that we chose were used:

Table 2. Synthesis of the techniques used in the Investigation

\begin{tabular}{|l|l|}
\hline $\begin{array}{l}\text { Research } \\
\text { Techniques }\end{array}$ & Objectives and ways of use \\
$\begin{array}{l}\text { Document } \\
\text { Analysis }\end{array}$ & $\begin{array}{l}\text { - We researched studies on this issue; } \\
\text { - Reading of reference works (primary and secondary sources); } \\
\text { - Longitudinal character; } \\
\text { - Complementarities with other procedures; } \\
\text { - Support for evidence of data: dialectic empiricism - theory - empiricism. }\end{array}$ \\
\hline \multirow{3}{*}{$\begin{array}{l}\text { Written Narratives } \\
\text { referencing; }\end{array}$} & $\begin{array}{l}\text { - Objectives were taken from clues dropped in direct speech in order to understand (Bogdan and Biklen, } \\
\text { 1994; Couto, 1998) the experiences of the professionals in terms of academic and professional } \\
\text { contextualisation and to know the meaning assigned to the work, their functions, their motivations and } \\
\text { difficulties and, ultimately, the mimetic character of the experiences (Flick, 2005). }\end{array}$ \\
\hline $\begin{array}{l}\text { Participant } \\
\text { Observation }\end{array}$ & $\begin{array}{l}\text { - Semi-structured, non-systematic (De Ketele and Roegiers, 1999; Sousa, 2009; Vilelas, 2009) using } \\
\text { predefined locations and dates but not the existence of rigid grids - only threads to guide advisors about } \\
\text { what to watch for, because all the behaviours and interactions were relevant ; }\end{array}$ \\
\hline
\end{tabular}




\begin{tabular}{|c|c|}
\hline & $\begin{array}{l}\text { - Descriptive and Narrative (Evertson and Green, 1986), direct (Bogdan and Bikle, 1994) and artificial } \\
\text { participant (Vilelas, 2009); } \\
\text { - Objectives were to contextualise the pedagogical practices developed, the forms of interpersonal } \\
\text { relationship, the profile of intervention, the verbal and non-verbal behaviours, i.e. the attitudes and } \\
\text { practices of the professionals for comparison with written records for in-depth understanding and not in } \\
\text { order to make generalisations; } \\
\text { - Notes were transcribed soon after the sessions in order to perform a first reflection, thus seeking to } \\
\text { ensure the validity and fidelity, checking accuracy, impartiality and objectivity within the inter-subjectivity; } \\
\text { - Limitations: (1) many events occurred at the same time, which made it difficult to record everything that } \\
\text { happened in detail; (2) an inability to carry out observation in France, which conditioned the comparative } \\
\text { aspects at this level (word vs. practice; Portugal vs. France); } \\
\text { - The duration was from March } 2010 \text { to April 2012. }\end{array}$ \\
\hline $\begin{array}{l}\text { Semi-directive } \\
\text { Interviews }\end{array}$ & $\begin{array}{l}\text { - Semi-directive: Scripts were used as a guide but with some flexibility about the introduction of other } \\
\text { issues relevant to the object of study; } \\
\text { - Objectives: (1) to perceive and to understand the feelings, opinions and representations of the } \\
\text { professionals; (2) to know the discourses on practices, experiences, ways of thinking, values; (3) to } \\
\text { confront words with practices observed; } \\
\text { - Selection of Interviewees: They came from the functions exercised in the participating bodies according } \\
\text { to their availability and accessibility. In France, one of the interviews was not conducted, due to the lack } \\
\text { of availability of the interviewee, despite several attempts being made; } \\
\text { - Advantages: It was possible to analyse with relative depth the meaning given by the social actors to the } \\
\text { experiences, practices and events of their daily lives, which enabled the creation of empathy and bonds } \\
\text { of trust with the interlocutors and the triangulation with data from Written Narratives and Participant } \\
\text { Observation. }\end{array}$ \\
\hline $\begin{array}{l}\text { Informal } \\
\text { Conversations }\end{array}$ & $\begin{array}{l}\text { - Objectives: These were to listen to opinions, to perceive senses, meanings, representations and needs } \\
\text { for comparison with other data; } \\
\text { - Timing: This was flexible and spontaneous and it occurred at the beginning or end of the sessions or at } \\
\text { any suitable intervals; } \\
\text { - Allowed to establish empathy, trust and exploit additional information. }\end{array}$ \\
\hline Logbook & $\begin{array}{l}\text { - Notes on objective facts and subjective perceptions in relation to the professionals and the observed } \\
\text { phenomena; } \\
\text { - Description and reflection about the investigative path: anxieties, hesitations, expectations, fears, } \\
\text { motivations, self-observation and self-knowledge (van Manen, 1990; Ramos and Gonçalves, 1996; } \\
\text { Moreira, 2005); } \\
\text { - The "Open book" was brought to life in the data analysis, thus providing clues to look beyond the } \\
\text { obvious and manifest. }\end{array}$ \\
\hline \multirow{2}{*}{$\begin{array}{l}\text { Questionnaire } \\
\text { Surveys }\end{array}$} & $\begin{array}{l}\text { Professionals on ETA Courses } \\
\text { - Do not involve generalisations (that are not representative of samples) but a complementary nature in } \\
\text { relation to the Multi-case Study; } \\
\text { - Statistical Treatment (SPSS versions } 18.0 \text { and } 20.0 \text { - Descriptive statistics: frequency and reliability } \\
\text { analysis) and emergent content analysis on open questions; } \\
\text { - Questions arranged in groups of subjects; closed, semi-open and open; nominal, ordinal, sorting and } \\
\text { non-comparative scales (Likert Scale). }\end{array}$ \\
\hline & $\begin{array}{l}\text { Trainees on ETA Courses } \\
\text { - Objectives: to compare information about the perspective of the trainees in relation to the image, } \\
\text { posture and work of the ETA Mediators, as well as the existence of conflicts, which provided data that we } \\
\text { compared with the oral and written discourses of the professionals (ETA Mediators); } \\
\text { - Pre-test: two ETA Courses - no change had to be done; } \\
\text { - Direct (in loco) application. }\end{array}$ \\
\hline
\end{tabular}

As shown in Table 2, we used several techniques for data collection, which resulted from a process of reflection about the nature of the study itself, its objectives and the information to be collected (Quivy and Campenhoudt, 2003), since "the methodological tools cannot be chosen independently of the theoretical references of the research" (Ruquoy, 2005, p. 86). Thus, the techniques selected were adapted to the object of study and to the type of information that we wanted to collect (Ruquoy, 2005, p. 86).

Therefore, we chose these techniques, because we considered that they would allow us to better meet the objectives of the investigation, that the information would be more relevant and that the respondents would respond better to the questions, because they allowed for the collection of more detailed or deeper information and because they 
allowed direct contact with the actors and their respective contexts of action.

\section{Data Analysis}

Grounded Theory was another methodological approach in which we focused our study given its inductive and emergent character, whose theoretical contributions came from the information of the analysis and processing of data.

Grounded theory is often used to make comparisons between cases, which happened in this work and, accordingly, Lessard-Hébert et al (2005, p. 167) point out that - in qualitative terms - researchers are concerned "to describe and understand particular cases (...) to, then, formulate more general theories from the comparison of several cases" i.e. they are worried about the so-called grounded theory.

As mentioned above, it assumes an inductive nature and involves the extraction of meaning from the data in order to contribute to theory building i.e. it emerges from the data and is substantive, thus, having practical utility (Glaser and Strauss, 1967; Merriam 1998; Flick, 2005; Maroy, 2005; Strauss and Corbin, 2008; Charmaz, 2009).

In fact our work was constantly shuttling between data and the theoretical referential, while being mediated by reflection and questioning about new information, since concepts that we could not foresee emerged during an investigation, (Glaser and Strauss 1967, 46) i.e. it involved a close relationship "between the collection and the interpretation of data" (Flick, 2005, p. 44) on the one hand, while on the other the very selection of the empirical material allowed us to realise the extent to which the strategies, methods, categories and theories were adequate to the object of study.

In this sense, we tried, throughout the investigative process "to be open to what happens in the studied scenes and in the interview statements, so that we can [could] learn about the lives of the participants in the research" (Charmaz, 2009 , p. 15) and, thereafter, we analysed experiences, discourses and our own intuitions to create concepts.

The collected data i.e. the words of the participants were, therefore, examined in order to study the content of the messages and to check the meanings implicit and explicit in the information from which we sought to build knowledge (Quivy and Campenhoudt, 2003).

Thus, the dialectic between data and theory was constant throughout the investigative path (Lüdke and André, 1986, p. 45) and "the methods and analysis procedures were multiple" (Maroy, 2005, p. 117).

The initial categories were developed from reading and re-reading the material, which allowed dividing them into parts, by topic, subject, problematic issue, etc (Lüdke and André, 1986). Nevertheless, those categories were not regarded as watertight compartments but we related them with each other and with the sub-categories that emerged from them and which corresponded to their properties (Glaser and Strauss 1967, Strauss and Corbin, 2008; Charmaz, 2009). Moreover, these initial categories were re-calculated and sub-divided or grouped into broader concepts, thus creating in the latter case the isotopy (Hiernaux, 2005).

In summary, we have based our analysis and processing of data on an emerging and inductive categorisation (Glaser and Strauss, 1967; Bogdan and Biklen 1994; Maroy, 2005; Strauss and Corbin 2008; Charmaz, 2009) but we did not reject the existence of previous questions, concepts and objectives of the research (Maroy, 2005). However, they were not local theories but questions and initial objectives and the process of data analysis was inductive, because we did not define a grid of analysis previous to the collection of data.

Therefore, we looked for the system that best suited our problems, issues and objectives of the research. That way other researchers could define other categories according to their representations, which could also happen to us at a later stage, because "you can look again at the data, having completed more research projects, and encode them differently", as Bogdan and Biklen (1994, p. 233) point out.

\section{Validity, Reliability and Ethics of the Investigation}

The validity and reliability were ethical concerns for us during the investigation, so we tried to maintain an objective stance (despite the familiarity with the topic and the subjectivity inherent in the methodology used), which was a nonjudgmental and non-intrusive posture and proceeded triangulation.

Our study focuses more on a perspective of internal validity rather than an external one, because there are not many investigations in the area, although the follow-up and comparison with other investigators have been maintained throughout the research process to ensure the external validation.

Our triangulation involved three aspects: triangulation of sources, triangulation of data and triangulation of techniques. So there was triangulation of cases with each other and their respective information and triangulation of data 
resulting from the application of the different techniques, which in turn were used in a direction of complementarity. The validity and reliability should, therefore, be considered and reflected on in relation to the paradigm in which the research takes place, the references that shape it and the objectives it seeks to achieve and these, along with the ethical issues, will define the quality of research.

Ethically, we tried to adopt by certain principles: respect for persons, informed consent, authenticity, confidentiality and anonymity, to have skills to develop the research, to protect participants against potential risks/damages, to maximise the positive results of the research and to promote justice and equity (Bogdan and Biklen, 1994; Miles and Huberman, 1994; Lessard-Hébert et al., 2005; Lima, 2006).

The research involves institutional responsibility to participants, colleagues, researchers and to society in general, hence the need to be guided by these assumptions.

In conclusion, "the important [thing] is that researchers act in a self-reflexive way and that they continuously revise their own values" (Lima, 2006, p. 156) and also that they share experiences, because the continued sharing of experiences and results is a way to verify and sustain the research (Lima, 2006, p. 156).

\section{Final Considerations}

The qualitative methodology involves a process of interpretation, where the objective is "to discover concepts and relationships in raw data and (...) organize these concepts and relationships in a theoretical explanatory scheme" (Strauss and Corbin, 2008, p. 24), presenting, according to Miles and Huberman (1994, p. 10), the following, as the main advantages: i) focussing on events that occur in their natural environment allows us to realise the "real life" situation; ii) it enables the understanding of latent information and, therefore, less obvious data; iii) it allows us to remain in the "field" for a long period of time, which facilitates the study of the processes; iv) it facilitates the perception of the meanings that the social actors attach to the events, processes, phenomena and structures that characterise their daily life.

In this sense, it appears that, when we fit into the educational domain, these advantages must be considered, especially, when the goals of the research involve the deep understanding of one or more educational phenomena, as in a case study or in a multi-case study, such as ours.

Our position does not preclude quantitative or mixed methodologies. They also have their advantages, as they are fundamental in certain types of studies, even in the educational field. Moreover, in our specific case we consider that the use of interpretation, comprehensiveness and direct access to social actors and phenomena, which the qualitative methodology allowed, in fact, demonstrated the potential of our work, thereby justifying our choice of this paradigm, which best suited our purposes from our point of view.

In conclusion, the most important things in an investigation are its appropriateness and consistency across all phases including the methodological options, which must constitute themselves as the guiding thread of the study in order to allow consistency between what is intended to achieve, what is realistic to achieve and, finally, what we can actually achieve.

\section{References}

Bogdan, R. and Biklen, S. (1994). Investigação Qualitativa em Educação. Porto: Porto Editora.

Bonafé-Schmitt, J-P (2010). Da mediação de bairro à mediação escolar: a outra mediação social. In J. A. Correia and A. M. C. e Silva (Eds.). Mediação: (D)os contextos e (D)os atores (pp. 45-58). Porto: ClIE - Centro de Investigação e Intervenção Educativas/Edições Afrontamento.

Charmaz, K. (2009). A construção da teoria fundamentada. Guia prático para análise qualitativa. Porto Alegre: Artmed Editora.

Coutinho, C. P. (2011). Metodologia de Investigação em Ciências Sociais e Humanas: Teoria e Prática. Coimbra: Edições Almedina.

Couto, C. G. (1998). Professor: O Início da Prática Profissional. Lisboa: Universidade de Lisboa (Tese de Doutoramento).

De Ketele, J-M \& Roegiers, X. (1999). Metodologia da recolha de recolha de dados: fundamentos dos métodos de observação, de questionários, de entrevistas, e de estudo de documentos. Lisboa: Instituto Piaget;

Demazière, D. \& Dubar, C. (1997). Analyser les entretiens biographiques. Paris: Éditions NATHAN.

Denzin, N. K. \& Lincoln, Y. S. (1994). Introduction: Entering the Field of Qualitative Research. In Norman K. Denzin and Yvonna S. Lincoln (Eds.), Handbook of Qualitative Research (pp. 1-17). Thousand Oaks: SAGE Publications.

Erlandson, D. A., Harris, E. L., Skipper, B. L. \& Allen, S. D. (1993). Doing Naturalistic Inquiry. A Guide to Methods. Newbury Park, SAGE Publications.

Evertson, C. \& Green, J. L. (1986). Observation as Inquiry and Method. In M. C. Wittrock (Ed.) Handbook of Research on Teaching (pp. 162-213). New York: MacMillan.

Flick, U. (2005). Métodos Qualitativos na Investigação Científica. Lisboa: Monitor. 
Freire, I. (2010). A mediação em educação em Portugal. In J. A. Correia e A. M. C. e Silva (Eds.). Mediação: (D)os contextos e (D)os atores (pp. 59-70). Porto: CIIE - Centro de Investigação e Intervenção Educativas/Edições Afrontamento.

Glaser, B. G. \& Strauss, A. (1967). The Discovery of Grounded Theory. Strategies for Qualitative Research. Chicago: Aldine;

Guba, E. \& Lincoln, Y. (1994). Competing Paradigms in Qualitative Research. In Denzin, N. e Lincoln, Y. (Eds.). Handbook of Qualitative Research (pp. 105-117). Thousand Oaks: SAGE Publications.

Haguette, T. M. F. (1995). Metodologias Qualitativas na Sociologia. Petrópolis: Vozes.

Hiernaux, J-P (2005). Análise estrutural de conteúdos e modelos culturais: aplicação a materiais volumosos. In L. Albarello, F. Digneffe, J.-P. Hiernaux, Ch. Maroy, D. Ruquoy and P. Saint-Georges, Práticas e Métodos de Investigação em Ciências Sociais (pp. 156202). Lisboa: Gradiva.

Kirk, J. \& Miller, M. L. (1986). Reliability and Validity in Qualitative Research. Newbury Park: SAGE Publications;

Lessard-Hébert, M., Goyette, G. \& Boutin, G. (2005). Investigação Qualitativa. Fundamentos e Práticas. Lisboa Instituto Piaget.

Lima, J. A. de (2006). Ética na Investigação. In J. A. de Lima and J. A. Pacheco (Eds.), Fazer Investigação. Contributos para a elaboração de dissertações e teses (pp. 127-159). Porto: Porto Editora.

Lüdke, M. \& André, M. (1986). Pesquisa em Educação: Abordagens Qualitativas. São Paulo: Editora Pedagógica e Universitária;

Maroy, C. (2005). A análise qualitativa de entrevistas. In L. Albarello, F.Digneffe, J.-P. Hiernaux, Ch. Maroy, D. Ruquoy e P. SaintGeorges, Práticas e Métodos de Investigação em Ciências Sociais (pp. 117-155). Lisboa: Gradiva.

Merriam, S. (1998). Qualitative Research and Case Studies Applications in Education. San Francisco: Jossey-Bass Publishers.

Miles, M. B. \& Huberman, A. M. (1994). Qualitative Data Analysis. An Expanded Source Book. Thousand Oaks: SAGE Publications.

Moreira, M. A. (2005). A investigação-ação na formação em supervisão no ensino do Inglês: Processos de (co-) construção de conhecimento profissional. Braga Universidade do Minho - Centro de Investigação em Educação (Tese de Doutoramento).

Neves, T. (2010). Modelos de mediação social. In J. A. Correia and A. M. C. e Silva (Eds.), Mediação: (D)os contextos e (D)os atores (pp. 33-43). Porto: CIIE - Centro de Investigação e Intervenção Educativas/Edições Afrontamento.

Patton, M. Q. (1990 [1980]). Qualitative Evaluation and Research Methods. London: SAGE Publications;

Quivy, R. \& Campenhoudt, L. (2003). Manual de Investigação em Ciências Sociais. Lisboa: Gradiva.

Ramos, M. A. \& Gonçalves, R. E. (1996). As narrativas autobiográficas do professor como estratégia de desenvolvimento e a prática da supervisão. In I. Alarcão (Ed.), Formação reflexiva de professores. Estratégias de supervisão (pp. 123-150). Porto: Porto Editora.

Ruquoy, D. (2005). Situação de entrevista e estratégia do entrevistador. In L. Albarello, F. Digneffe, J.-P. Hiernaux, Ch. Maroy, D. Ruquoy eandP. Saint-Georges, Práticas e Métodos de Investigação em Ciências Sociais (pp. 84-116). Lisboa: Gradiva.

Silva, A. M. C. \& Moreira, M. A. (2009). Falar e escrever de formação e mediação no contexto atual. In A. M. C. Silva e M. A. Moreira (Eds.), Formação e Mediação Sócio-educativa. Perspetivas Teóricas e Práticas (pp. 6-13). Porto: Areal Editores.

Silva, A. M. C., Caetano, A. P., Freire, I., Moreira, M. A., Freire, T. \& Ferreira, A. S. (2010). Novos atores no trabalho em educação: os mediadores socioeducativos. In Revista Portuguesa de Educação, 23(2), 119-151. Braga: ClEd - Universidade do Minho. Available at http://www.scielo.gpeari.mctes.pt/scielo.php?pid=S0871-91872010000200006\&script=sci_arttext.

Sousa, A. B. (2009). Investigação em Educação. Lisboa: Livros Horizonte.

Stake, R. E. (1994). Case Studies. In Norman K. Denzin e Yvonna S. Lincoln (Eds.), Handbook of Qualitative Research (pp. 236247).Thousand Oaks: SAGE Publications.

Stake, R. E. (2009). A Arte da Investigação com Estudos de Caso. Lisboa: Fundação Calouste Gulbenkian.

Strauss, A. \& Corbin, J. (2008). Pesquisa Qualitativa: Técnicas e procedimentos para o desenvolvimento de teoria fundamentada. Porto Alegre: Artmed.

Tuckman, B. (2000). Manual de Investigação em Educação. Lisboa: Fundação Calouste Gulbenkian.

Van Manen, M. (1990). Researching lived experience: human science for na action sensitive pedagogy. New York: State university of New York Press.

Vilelas, José (2009). Investigação - O Processo de Construção do Conhecimento. Lisboa: Edições Sílabo.

Yin, R. K. (2010 [2009]). Estudo de Caso. Planejamento e Métodos. Porto Alegre: Bookman Companhia Editora. 